\title{
Glehnia littoralis Root Extract Induces G0/G1 Phase Cell Cycle Arrest in the MCF-7 Human Breast Cancer Cell Line
}

\author{
Joseph Flores de la Cruz ${ }^{1}$, Emil Joseph Sanvictores Vergara ${ }^{2}$, Yura Cho², Hee \\ Ok Hong ${ }^{3}$, Baatartsogt Oyungerel $^{4}$, Seong Gu Hwang ${ }^{2 *}$
}

\begin{abstract}
Glehnia littoralis (GL) is widely used as an oriental medicine for cough, fever, stroke and other disease conditions. However, the anti-cancer properties of GL on MCF-7 human breast cancer cells have not been investigated. In order to elucidate anti-cancer properties and underlying cell death mechanisms, MCF-7cells $\left(5 \times ~_{10}^{4} /\right.$ well) were treated with Glehnia littoralis root extract at $0-400 \mathrm{ug} / \mathrm{ml}$. A hot water extract of GL root inhibited the proliferation of MCF-7 cells in a dose-dependent manner. Analysis of the cell cycle after treatment of MCF-7 cells with increasing concentrations of GL root extract for 24 hours showed significant cell cycle arrest in the G1 phase. RT-PCR and Western blot analysis both revealed that GL root extract significantly increased the expression of p21 and p27 with an accompanyingdecrease in both CDK4 and cyclin D1. Our reuslts indicated that GL root extract arrested the proliferation of MCF-7 cells in G1 phase through inhibition of CDK4 and cyclin D1 via increased induction of p21 and p27. In summary, the current study showed that GL could serve as a potential source of chemotherapeutic or chemopreventative agents against human breast cancer.
\end{abstract}

Keywords: Glehnia littoralis - human breast cancer - MCF-7 human breast cancer cells

Asian Pac J Cancer Prev, 16 (18), 8113-8117

\section{Introduction}

Glehnia littoralis is a perennial herb that grows in the coastal areas of Northern Pacific countries (Kong et al., 2010; Kong and Yuan, 2010; Taesook et al., 2010; Young et al., 2010) and is used as traditional medicine in East Asian countries like China, Japan and Korea (Kong and Yuan, 2008; Taesook et al., 2010; Yoon et al., 2010). In folkloric medicine the dried roots and rhizomes of this plant are used as antipyretic, analgesic, diaphoretic, anti-inflammatory, antihypertensive and anticancer agents (Kong and Yuan, 2008; Hwang et al., 2010; Kong et al., 2010; Lee et al., 2014). Several researches have already been done on this plant and it has been reported to possess antioxidant (Hwang et al., 2010) and anti-inflammatory (Taaesook et al., 2010, Lee et al., 2014) activities. Moreover, it has also been shown to have cytotoxic activity against some forms of human cancer cell lines such as colorectal (Young et al., 2010), gastric, fibrosarcoma and leukemia (Chang-Suk et al., 2010). Analysis of the roots showed that compounds such as furanocoumarin, polyacetylene, flavonoid, lignin, monoterpenoid glycoside and pyranocoumarins to be present (Lee et al., 2014). Coumarins and polyacetylenes were shown in a study to be partly responsible for the anti-proliferative effects shown by crude extracts of this plant (Kong et al., 2010).

With plant-derived compounds and their semi-synthetic and analogs as promising sources of pharmaceuticals for human diseases, the screening of plants with ethnopharmacological use is now an increasing trend in the search for potential anticancer treatments. Several researches have already showed positive antitumor effects of several plant extracts against different cancer cell lines (Byambaragachaa et al., 2013; Byambaragachaa et al., 2014; Chu et al., 2014; dela Cruz et al., 2014). In fact, several plant-derived compounds have already been approved for use against human cancer (Cochrane et al., 2008).

Breast cancer is the most frequently diagnosed neoplasm and is the leading cause of cancer-related deaths in women worldwide with about half of the cases and $60 \%$ of deaths estimated to occur in developing countries (Jemal et al., 2011). In the United States alone, almost 3 million women are already living with breast cancer as of 2011. In addition, 2009-2011 data have predicted that around 12.3 percent of women will be diagnosed with breast cancer at some point in their lifetime.

Normally, cell division is tightly regulated such that

${ }^{I}$ Department of Basic Veterinary Sciences, College of Veterinary Medicine, University of the Philippines Los Baños, the Philippines, ${ }^{2}$ Department of Animal Life and Environmental Science, Hankyong National University, ${ }^{3}$ Department of Medical Science, School of Medicine, Konkuk University, Korea, ${ }^{4}$ Department of Biotechnology and Breeding, School of Animal Science and Biotechnology, Mongolian University of Life Sciences, Ulan Batoor, Mongolia*For correspondence: sghwang@hknu.ac.kr 
aberrations or damage, whether internal or external, leads to a cascade of events ultimately causing cessation of division. Cancer cells, however, have an unregulated cell cycle due to either the overexpression of genes responsible for the entry of cells from one cell cycle phase to another and/or the underexpression of genes responsible for the promotion of cell cycle arrest (Walworth 2000).

This study aims to determine the cytotoxic effect of the hot water extract of Glehnia littoralis roots on MCF-7 human breast cancer cell line. In addition, the mechanism of action of the extract related to its cytotoxicity was elucidated through the detection of cell cycle- related genes and proteins.

\section{Materials and Methods}

\section{Plant material and extract preparation}

The roots were subjected to a freeze-drying system for 24 hours to obtain the dried root sample which was pulverized to powder form. Afterwards, hot water extraction was done by boiling $\left(90^{\circ} \mathrm{C}\right.$ for 4 hours $) 100 \mathrm{~g}$ powdered roots in $1000 \mathrm{~mL}$ distilled water. The resulting hot water extract was filtered and placed in the deep freezer $\left(-80^{\circ} \mathrm{C}\right)$ overnight and again subjected to freeze-drying system to obtain the powdered crude aqueous extract. The resulting product was stored in the deep freezer.

\section{Cell lines and cell culture}

MCF-7 breast cancer cells was obtained from the Korean Cell line Bank (KCLB) and were cultured in Dulbeco's Modified Eagle's Medium (DMEM) supplemented with $10 \%$ heat inactivated fetal bovine serum (FBS) and Penicillin/Streptomycin $(100 \mathrm{U} / \mathrm{mL})$ and $3.7 \mathrm{mg} / \mathrm{mL}$ of $\mathrm{NaHCO} 3$ at $37^{\circ} \mathrm{C}$ in $5 \% \mathrm{CO}_{2}$.

\section{Cell viability analysis}

Cell counting kit-8 (CCK-8, Dojindo, Japan) was used to quantify cell viability according to the manufacturer's instruction. The cells were seeded at a density of 104 cells per well and were incubated in DMEM at $37^{\circ} \mathrm{C}$ in $5 \% \mathrm{CO}_{2}$ for $24 \mathrm{hrs}$. Then the cells were pretreated with GL extract $(0,50,100,200$ and $400 \mu \mathrm{g} / \mathrm{mL})$ and incubated for 24 and 48 hours. Following treatment, the media in the wells were suctioned and $100 \mu \mathrm{L}$ of fresh media with $10 \mu \mathrm{L}$ CCK-8 was added per well and the plate was incubated at $37^{\circ} \mathrm{C}$ for 2 hours. Absorbance at 450nm was measured using an ELISA plate reader (Tecan, Switzerland). Viability of the treated cells was expressed as the percentage of control cells.

\section{Cell cycle analysis by flow cytometry}

In order to determine the proportion of $\mathrm{MCF}-7$ cells in the various stages of the cell cycle, flow cytometry analysis was used. Cells were seeded at a density of $5 \mathrm{x}$ $105 / \mathrm{mL}$ in 6 - well plates and were allowed to attach for 12 hours. Afterwards, the wells were treated with different concentrations of GL extract $(0,50100,200$ and $400 \mu \mathrm{g} /$ $\mathrm{mL}$ ) for 24 hours. The cells were then harvested and fixed with of absolute ethanol for 2 hours at $-20^{\circ} \mathrm{C}$. Afterwards, ethanol was removed by centrifugation then resuspended with PBS. The cells were then treated with RNAse A (50 $\mu \mathrm{g} / \mathrm{mL})$ and propidium iodide $(50 \mu \mathrm{g} / \mathrm{mL})$ prior to analysis using FACSCalibur Flow Cytometer (Becton Disckson, USA). 10000 events were evaluated for all samples. The percentage of cells in G0/G1, S and G2/M phases were calculated using BD Cellquest Pro software.

RNA isolation and Reverse transcriptase - Polymerase Chain Reaction (RT-PCR)

Total RNA was obtained from GL treated $(0,50$, 100,200 and $400 \mu \mathrm{g} / \mathrm{mL}$ ) cells using Trizol reagent (Invitrogen, MA, USA) according to the manufacturer's instructions. $1 \mu \mathrm{g}$ of RNA was used to obtain the complementary DNA (cDNA) using the protocol provided by M-MuLV reverse transcriptase (Fermentas, Lithuania). Specific primers (Table 1) were used to amplify the genes p21, p27, CDK4 and Cyclin D1. PCR products were then separated by electrophoresis using $2 \%$ agarose stained with ethidium bromide and UV transillumination was done afterwards.

\section{Western blotting}

Cells that had undergone treatment with GL extract $(0$, $50,100,200$ and $400 \mu \mathrm{g} / \mathrm{mL}$ ) for 24 hours were lysed with a protein extraction solution (Intron Biotechnology). The protein concentration was determined using the Bio-Rad protein assay (Bio-Rad Laboratories, Richmond, CA). Separation of $30 \mu \mathrm{g}$ of the extracted protein was carried out in 10 and $12 \%$ SDS-PAGE. Afterwards it was transferred to a nitrocellulose membrane (Schleicher and Schuell, Germany) and incubated overnight with $5 \%$ skim milk in TBST buffer (20mM Tris- $\mathrm{HCl}, \mathrm{pH} 7.6,140 \mathrm{mM} \mathrm{NaCl}$, $0.1 \%$ Tween 20 ). The membrane was washed four times with TBST and incubated for 2 hours in $2 \%$ skim milk containing the primary antibodies (monoclonal anti-p21, anti-p27, anti-CDK4 and anti-cyclin D1) at 1:1000 dilution. The blot was washed with TBST buffer four times and incubated with horse radish peroxidase-labeled secondary antibody (Santa Cruz Biotechnology) diluted to 1:2000 for 2 hours. The membranes were washed four times and detection was done with the use of the enhanced chemiluminesence system (ECL, Western Blot Analysis System Kit, Amersham Biosciences).

\section{Statistical analysis}

All experiments were done in triplicates and data were expressed as means $\pm \mathrm{SD}$. The difference between control and GL treated cells were evaluated using oneway ANOVA followed by Duncan Multiple Range Test. $P$ values less than 0.05 were considered statistically significant.

\section{Results}

\section{GL causes inhibition of MCF-7 cell proliferation}

The viability of MCF-7 breast cancer cells treated with various concentrations of GL extract was measured using CCK-8 assay. As shown in Figure 1, GL extract was able to cause cytotoxicity towards the cells in a dose-dependent manner but not in a time dependent manner (data not shown). The data is suggestive of the concentration dependent inhibition in MCF-7 cells with an IC50 value 
of $158.63 \mu \mathrm{g} / \mathrm{mL}$ after 24 hours of incubation.

GL extract induces $G 0 / G 1$ phase cell cycle arrest in MCF-7 cells

The effect of 24 hours of treatment with varying concentrations of GL extract on the cell cycle of MCF7 breast cancer cell line was determined using flow cytometry. Figure 2 shows the relative percentages of MCF-7 cells in each phase of the cell cycle following treatment. It is shown that there is a dose dependent increase in the percentage of cells in the G0/G1 phase of the cell cycle from $63.89 \%$ (control) to $72.24 \%(400 \mu \mathrm{g} /$ $\mathrm{mL}$ ). The G0/G1 phase cell cycle arrest was accompanied by a decrease in the percentage of cells in the S and G2/M phase of the cell cycle. The reduction in the number of cells undergoing DNA synthesis was also in a dose dependent manner with $8.5 \%$ for the control and $6 \%$ for the $400 \mu \mathrm{g} /$ $\mathrm{mL}$ of treatment. The FACS data shown in this study demonstrated that GL extract inhibited cell proliferation of MCF-7 cells during the G0/G1 phase of the cell cycle.

GL extract induced changes on the expression of cell-cycle related genes

To understand the mechanism upon which GL extract induces cell cycle arrest in MCF-7 cells, the expression of cell-cycle related genes were examined using RT-PCR (Figure 3 and Figure 4). RT-PCR analysis shows a dosedependent increase and decrease in the expression of cell cycle inhibitory genes (p21 and p27) and cell cycle

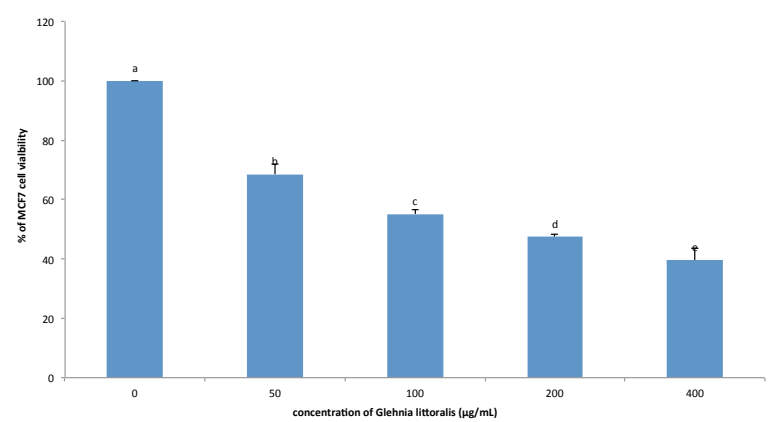

Figure 1. ?? The effect of Different Concentrations (0$400 \mu \mathrm{g} / \mathrm{mL}$ ) of Aqueous extract from Glehnia Littoralis Root on the Viability of MCF7 Cells Incubated after 24 hours

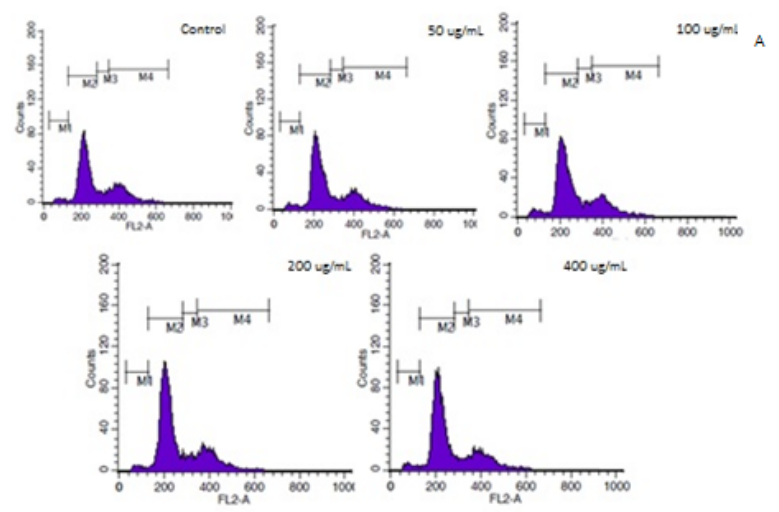

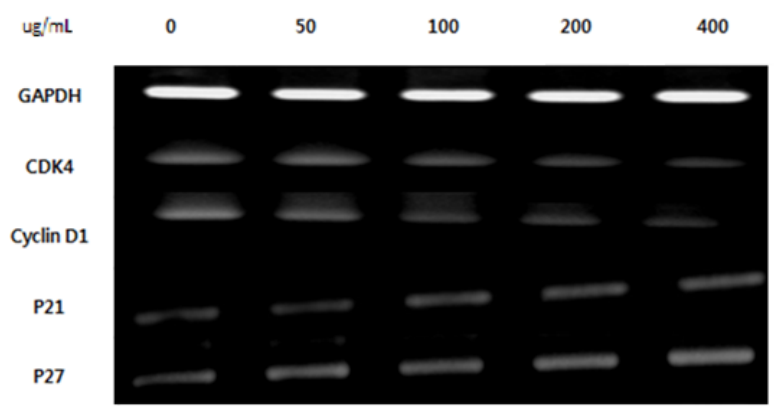

Figure 3. The Effect of Treatment with Glehnia Littoralis Root Extract on mRNA Expressions of Cell Cyclerelated Genes in MCF-7 Cells

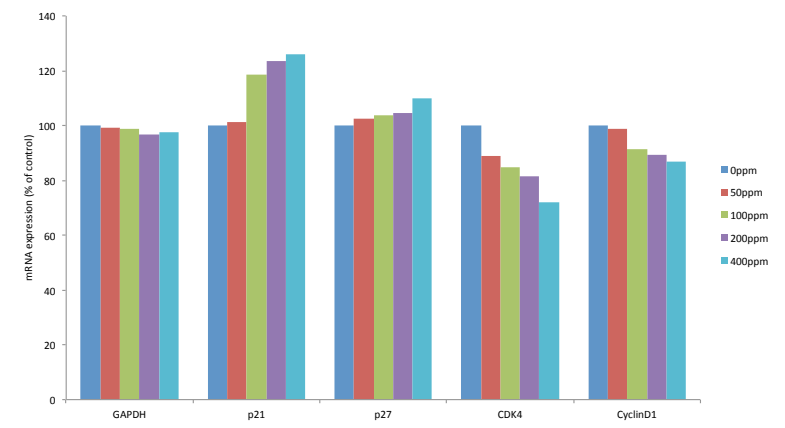

Figure 4. Histogram Showing the Effect of Glehnia Littoralis Root Extract in the Expression Cell Cycle Related Genes in MCF-7 Cells

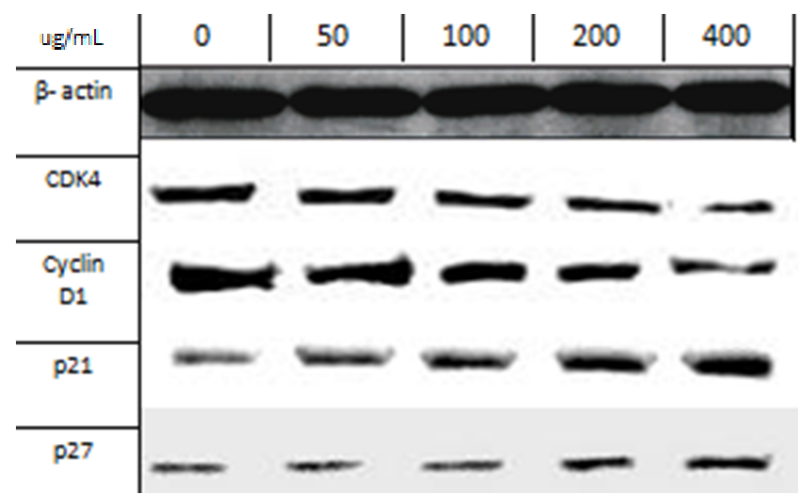

Figure 5. The Effect of Increasing Concentrations of Glehnia Littoralis Root Extract on the Expression of Cell-cycle Related Proteins

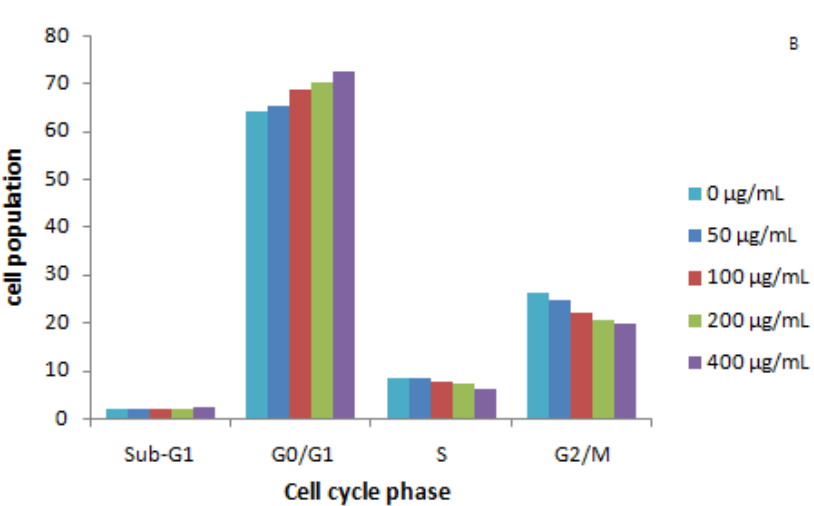

Figure 2. The Effect of Different Concentrations $(0-400 \mu \mathrm{g} / \mathrm{mL})$ of Aqueous Extract from Glehnia Littoralis Root on the Cell Cycle of MCF7 Cells. (A) Cell cycle distribution of GL treated cells after flow cytometry (B) Histogram showing the distribution of the cells in each phase of the cell cycle 
Table 1.Primer sequence of the genes used in the study

\begin{tabular}{ll}
\hline Target Gene & Primer Sequence (5'-3') \\
\hline GAPDH & Forward: CGCTCTCTGCTCCTCCTGTT \\
& Reverse: CCATGGTGTCTGAGCGATGT \\
CDK4 & Forward: GGCCCTCAAGAGTGTGAGAG \\
& Reverse: TACCTTGATCTCCCGGTCAG \\
Cyclin D1 & Forward: AACTACCTGGACCGCTTCCT \\
& Reverse: CCACCTGAGCTTGTTCACCA \\
p21 & Forward: GGAGACTCTCAGGGTCGAAA \\
& Reverse: GGATTAGGGCTTCCTCTTGG \\
p27 & Forward: GGGGCTCGTCTTTCGGGGTGTTT \\
& Reverse: GAGCGGGAGGGCGGAGAGGAG \\
\hline
\end{tabular}

promoting genes (CDK4 and Cyclin D1), respectively, after 24 hours of treatment.

\section{Effect of GF extract on the expression of cell-cycle related proteins}

To further elucidate the mechanism upon which GL extract induces cell cycle arrest in MCF-7 cells, the expression of cell-cycle related proteins was determined using Western blot analysis (Figure 5). Results of the Western blot analysis shows a dose-dependent increase in the expression of proteins related to the promotion of the cell cycle (CDK4 and Cyclin D1) accompanied with a decrease in the expression of cell cycle inhibitory proteins (p21 and p27) after treatment for 24 hours.

\section{Discussion}

Extracts from Glehnia littoralis have already been proven to have anti-inflammatory (Taesook et al., 2010; Lee et al., 2014) and anticancer activity against HT-29 human colorectal cancer (Young et al., 2010), AGS human gastric cancer, HT1080 human fibrosarcoma and U937 human leukemia cell lines (Kong et al., 2010). Although the anticancer potential of Glehnia littoralis root extract has been proven in past studies, its effect on the proliferation of MCF-7 human breast cancer cell line and its mechanism of action has not yet been determined.

The results of the cell viability assay have shown a dose dependent decrease in the cell line used in the study with as much as $68.53 \%, 55.15 \%, 47.38 \%$ and $39.57 \%$ reduction in the cells at 50,100, 200 and $400 \mu \mathrm{g} / \mathrm{mL}$ concentration of the GL extract, respectively, after 24 hours of treatment. This data shows that even at low concentrations, the extract has strong anti proliferative effects against MCF7 cancer cells. In this regard, GL aqueous extract can be a potential source of an isolate which can be used as a chemopreventative or chemotherapeutic agent.

Inhibition of the progression of the cell cycle is an important strategy for the control of cancer growth (Qui et al., 2011). In this study, flow cytometry analysis has shown that the extract induces both a dose dependent increase in the percentage of cells in the G0/G1 phase of the cell cycle accompanied by a dose-dependent decrease in the percentage of cells in the S (DNA synthesis) phase. This observation is indicative that the extract induces cell cycle arrest at the G0/G1 phase of the cell cycle. To elucidate the mechanism upon which cell cycle arrest occurs in the cells, qualitative measurement of cell cycle related genes CDK4, Cyclin D1, p21 and p27 was performed using RT-PCR assay. The transition of the cell cycle from one phase to another is dependent upon the regulation of cyclin-dependent kinases (CDK)/cyclin complexes, an active agent that phosphorylates substrates involved in cell cycle progression. $\mathrm{G} 1$ to $\mathrm{S}$ phase of the cell cycle progression is controlled by a number of cyclin members, including CDK4 and Cyclin D1. Previous studies have shown that the over expression of CDK4 and cyclin D is seen in many human cancers (Vermuelen et al., 2003) and thus presents an excellent target in the search of possible chemotherapeutic and chemopreventative agents. CDK inhibitors (CKI) also play a crucial role in the cell cycle. CKIs bind to either CDK alone or to the CDK/Cyclin complex to regulate CDK activity and cause cell cycle arrest. p21 and p 27 belong to the Cip/Kip family of CKIs which cause cell cycle arrest specifically by inactivating the CDK/Cyclin D complex in the G1 phase. In addition, p21 has also been shown to inhibit DNA synthesis (Walworth 2000; Vermuelen et al., 2003). With this, CDK4 and Cyclin D1 are regarded as tumor promoting genes while p21 and p27 as tumor suppressor genes.

Both RT-PCR and Western blot analysis shows a dosedependent decrease in the expression of the two tumor promoters, cyclin D and CDK4, explaining the cell cycle arrest observed during the G0/G1 phase. In addition, the expression of the CKIs (tumor suppressors) used in the study, p21 and p27, were increased dose dependently. The increase in both the gene and protein expression of the CKIs support the finding that the GL extract induces cell cycle arrest in MCF-7 breast cancer cells via the inhibition of the activity of CDK4/Cyclin D complex.

Results obtained from this study demonstrate the cytostatic effect of GL aqueous extract on MCF-7 breast cancer cells through the decreased expression of cell cycle-related genes and proteins. These findings show that Glehnia littoralis roots can be a potential source of a chemotherapeutic or chemopreventative agent against breast cancer.

\section{References}

Byambaragchaa M, dela Cruz J, Kh A, et al (2014). Anticancer potential of an ethanol extract of saussurea involucrata against hepatic cancer cells in vitro. Asian Pac J Cancer Prev, 15, 7527-32.

Byambaragchaa M, de la Cruz J, Yang SH, et al (2013) Anti-metastatic potential of ethanol extract of saussurea involucrata against hepatic cancer in vitro. Asian Pac J Cancer Prev, 14, 5937-5402.

Chu XT, de la Cruz J, Hwang SG, et al (2014). Tumorigenic effects of endocrine-disrupting chemicals are alleviated by licorice (Glycyrrhiza glabra) root extract through suppression of AhR Expression in mammalian cells. Asian Pac J Cancer Prev, 15, 4809-13.

Cochrane CB, Nair PKR, Melnick SJ, Resek AP, et al (2008). Anticancer effects of annona glabra plant extracts in human leukemia cell lines. Anticancer Res, 28, 965-972.

de la Cruz J, Kim DH, et al (2014) Anti cancer effects of cnidium officinale makino extract mediated through apoptosis and 
Glehnia littoralis Root Extract Induces G0/G1 Phase Cell Cycle Arrest in MCF-7 Human Breast Cancer Cells cell cycle arrest in the HT-29 human colorectal cancer cell line. Asia Pac J Cancer Prev, 15, 5117-21.

Hwang KA, Hwang YJ, Park DS, et al (2010). In vitro investigation of antioxidant and anti-apoptotic activities of Korean wild edible vegetable extracts and their correlation with apoptotic gene expression in HepG2 cells. Food Chem, 125, 483-7.

Kong CS, Um YR, Lee JI, et al (2010). Constituents isolated from Glehnia littoralis suppress proliferations of human cancer cells and MMP expression in HT1080 cells. Food Chem, 120, 385-94.

Jemal A, Bray F, Center MM, et al (2011). Global Cancer Statistics. CA CANCER J CLIN. 61, 69-90

Kong WX and Yuan Z (2008). New lignan glycosides from Glehnia littoralis. Chin Chem Lett, 19, 1459-61.

Lee JW, Lee C, Jin Q, et al (2014). Pyranocoumarins from Glehnia littoralis inhibit the LPS-induced NO production in macrophage RAW 264.7 cells. Bioorg Med Chem Lett, 24, 2717-9.

Qui P, Guan H, Dong P, et al (2011). The p53-, Bax- and p21-dependent inhibition of colon cancer cell growth by 5-hydroxy polymethoxyflavones. Mol Nutr Food Res, 55, 613-22.

Um YR, Kong CS, Lee JI, et al (2010). Evaluation of chemical constituents from Glehnia littoralis for antiproliferative activity against HT-29 human colon cancer cells. Process Biochem, 45, 114-9.

Vermuelen K, Van Bockstaele DR and Berneman ZN (2003). The cell cycle: a review of regulation, deregulation and therapeutic targets in cancer. Cell Prolif, 36, 131-149.

Walworth NC (2000). Cell-cycle checkpoint kinases: checking in on the cell cycle. Curr Opin Cell Biol, 12, 697-704.

Yoon T, Lee do Y, Lee AY, et al (2010). Anti-inflammatory effects of Glehnia littoralis extract in acute and chronic cutaneous inflammation. Immunopharmacol Immunotoxicol, 32, 663-70.

Yoon T, Cheon MS, Lee AY, et al (2010). Anti-inflammatory activity of methylene chloride fraction from Glehnia littoralis extract via suppression of NF- $x \mathrm{~B}$ and mitogenactivated protein kinase activity. J Pharmacol Sci, 112, 46-55. 